\title{
INCREASE OF BIOGAS PRODUCTION THROUGH CO-DIGESTION OF LIPIDS AND SEWAGE SLUDGE
}

\author{
C. NOUTSOPOULOS* \\ D. MAMAIS \\ K. ANTONIOU \\ C. AVRAMIDES
}

Received: 05/12/11

Accepted: 09/03/12

\author{
National Technical University of Athens, Faculty of Civil Engineering \\ Department of Water Resources and Environmental Engineering \\ 5, Iroon Polytechniou, Zografou, Athens 15780, Greece
}

\begin{abstract}
The aim of this study was to assess the feasibility of co-digesting lipids originated from domestic wastewater along with sewage sludge. Three lab-scale single stage mesophilic anaerobic digesters were operated under a constant hydraulic retention time (15 days). One system (C) was fed on a daily basis with sewage sludge and served as the control system and its operation was compared with two experimental systems (E1 and E2). Both experimental systems received mixtures of sludge and lipids with different lipids content (20\% for system E1 and $60 \%$ for system E2 on a VS basis), whereas organic loadings were $2 \mathrm{KgVS} \mathrm{m}^{-3} \mathrm{~d}^{-1}$ and $3,5 \mathrm{KgVS} \mathrm{m}^{-3} \mathrm{~d}^{-1}$ for systems E1 and E2, respectively.

According to the results it can be stated that the addition of lipids to sewage sludge up to $60 \%$ on a VS basis resulted in a significant increase of biogas production without producing any severe effects on the properties of the digested sludge. More specifically biogas production of reactor E1 was $18 \%$ greater than that of reactor $\mathrm{C}$, whereas biogas produced in reactor $\mathrm{E} 2$ was even greater $(50 \%$ higher than that of reactor $\mathrm{C}$ ). Finally it is interesting that during start-up a lag phase was recorded at reactor E2 before biogas production initiated, which should be attributed to the time required for growth of acetogenic bacteria capable to degrade LCFA.
\end{abstract}

KEYWORDS: biogas, co-digestion, grease, lipids, long chain fatty acids, methane potential, sewage sludge.

\section{INTRODUCTION}

Lipids (fats, oils, greases) constitute a major part of domestic wastewater organic matter which accounts for the 25-35 \% of the total COD of the raw wastewater (Quemeneur et al., 1994; Raunkjaer et al., 1994; Chipasa et al., 2006). The entrance of significant lipids quantities in a biological reactor is related with various operational problems like biological bulking and foaming (Mamais et al., 1998; Andreasen et al., 1998; Noutsopoulos et al., 2007; Noutsopoulos et al., 2010), or contribution to the effluent concentration of organic matter.

Several physical methods (i.e. trapping, interception, use of skimmers, air flotation) have been employed in order to prevent lipids passing through an activated sludge system which contribute to significant lipids removal (to the order of 70-90 \%). The major practice for transporting and disposal of the accumulated lipids is traditionally landfilling. However due to the continuously stricter environmental legislation regarding the management of such biodegradable wastes, treatment of lipids became in some cases an unavoidable practice.

Lipids are very promising substrate for anaerobic digestion in terms of methane production when compared to carbohydrates and proteins and thus they might be regarded as a potential energy source (Hanaki et al., 1981; Angelidaki et al., 1997; Kim et al., 2004; Alves et al., 2009). Lipids originated in wastewater consist mainly of triglycerides and free long chain fatty acids (LCFA). Several biochemical pathways are related to lipids degradation under anaerobic conditions. 
Triglycerides are firstly hydrolysed into free LCFA and glycerol; a process which is catalysed by extracellular enzymes called lipases. Degradation of free LCFAs and glycerol is taking place intracellularly. Glycerol is converted mainly to acetate by acidogenic bacteria whereas LCFA are transformed to acetate (or propionate), hydrogen and $\mathrm{CO}_{2}$ via $\beta$-oxidation metabolic pathway (syntrophic acetogenesis). The last step during anaerobic digestion is methanogenesis (hydrogenotrophic and acetotrophic). However the theoretical methane yield of lipids $\left(1 \mathrm{I} \mathrm{CH}_{4} \mathrm{~g}^{-1}\right.$ lipids) is not always achievable due to their inhibition effect to anaerobic biocenosis. The main mechanisms of LCFA toxicity is through their adsorption onto the cell wall of microorganisms thus inhibiting transport phenomena (Hwu et al., 1998; Cirne et al., 2007) and acute toxicity on microbial activity of both aceticlastic and hydrogenotrophic methanogens (Angelidaki et al., 1992; Rinzema et al., 1994).

Since single substrate anaerobic digestion of lipids is not a feasible practice due to the aforementioned inhibition phenomena, the in-situ digestion of lipids along with sludge (primary and surplus biological) produced in a wastewater treatment plant seems an interesting approach.

There are several studies suggesting that an increased methane yield can be achieved through codigestion of sewage sludge with lipid-based material (especially grease trap sludge). More specifically Luostarinen et al. (2009) and Kabouris et al. (2009) report an increase of methane yield to the order of $60 \%$ and $260 \%$ for grease trap sludge addition (from a meat processing plant in the former study and from restaurants and other facilities in the latter study) of $46 \%$ and $48 \%$ of the total feed volatile solids load respectively. Furthermore Davidsson et al. (2008) report an increase on methane yield of $9-27 \%$ when $10-30 \%$ of grease trap sludge (on a VS basis) was digested along with sewage sludge.

The aim of the present study was to assess the feasibility of co-digesting lipids originated from domestic wastewater along with sewage sludge and to evaluate the effect of the organic loading and lipids content on the performance of anaerobic digestion.

\section{EXPERIMENTAL MATERIALS AND METHODS Inoculum and substrates}

All systems were inoculated with mesophilic digested sludge from Psyttalia Wastewater Treatment Plant (PWTP). PWTP is located in the greater Attiki region and is treating an average wastewater flow of $750,000 \mathrm{~m}^{3} \mathrm{~d}^{-1}$. Primary (PS) and waste activated sludge (WAS) after thickening are fed to mesophilic anaerobic digestion tanks at a feed ratio of $74 \%$ PS and $26 \%$ WAS. The aforementioned mixture of PS and WAS thickened sludge from PWTP was used as sewage sludge (SS) substrate in the present study. Furthermore grease sludge (GS) originated from PWTP was also used as a co-substrate in some experiments. GS was collected from the primary settling tanks of PWTP through surface skimming. Based on laboratory analyses grease sludge exhibits a high organic content (VS/TS ratios of over $90 \%$ ) and adverse rheological characteristics. SS and GS were shipped to the laboratory once a week and upon delivery they were stored at $4^{\circ} \mathrm{C}$ after being analyzed for total and volatile solids concentrations.

\section{Continuous anaerobic digestion systems}

Three lab-scale single stage mesophilic anaerobic digesters were operated under a constant hydraulic retention time $(15 \mathrm{~d})$ for various organic loadings and sewage sludge - grease sludge mixtures for a period of 140 days (Figure 1). All systems were inoculated with mesophilic digested sludge. One system (C) was fed on a daily basis with a mixture of thickened PS and WAS (SS) from PWTP and served as the control system and its operation was compared with two experimental systems (E1 and E2). Both experimental systems received mixtures of SS and GS with different GS content ( $20 \%$ for system E1 and $60 \%$ for system E2 on a VS basis). Average organic loading of the three experimental units were equal to $2 \mathrm{~kg} \mathrm{VS} \mathrm{m}^{-3} \mathrm{~d}^{-1}$ for systems $C$ and $\mathrm{E} 1$ and $3,5 \mathrm{~kg} \mathrm{VS} \mathrm{m}^{-3} \mathrm{~d}^{-1}$ for system E2. System E1 was operated at a high organic loading of $8 \mathrm{~kg} \mathrm{VS} \mathrm{m}^{-3} \mathrm{~d}^{-1}$ and a GS content of $90 \%$ (on VS basis) for a period of 16 days and thereafter it was operated at the aforementioned conditions (at an organic loading of $2 \mathrm{~kg} \mathrm{VS} \mathrm{m}^{-3} \mathrm{~d}^{-1}$ and a GS content of $20 \%$ on a VS basis). The characteristics of inoculum material and the feed mixtures of the three experimental units are summarized in Table 1 (average values are presented). 


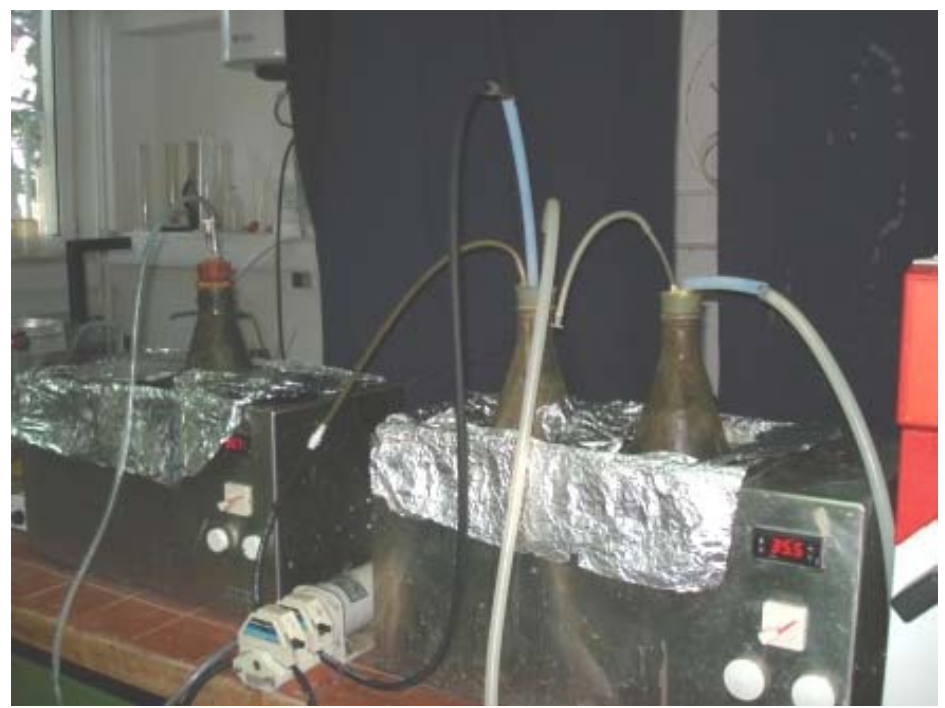

Figure 1. The three lab-scale anaerobic digestions units

Feeding of the experimental units and withdrawing was carried out once per day. Mixing of the digesters was performed through magnetic stirrers.

Table 1. Characteristics of the inoculum and feed substrates to the three experimental anaerobic digestion units

\begin{tabular}{lcccc}
\hline Parameter & Inoculum & System C & System E1 & System E2 \\
\hline TS $(\%)$ & 2.6 & 4.1 & 3.7 & 6.2 \\
VS $(\%)$ & 1.6 & 3.1 & 3.0 & 5.3 \\
VS/TS $(\%)$ & 61 & 75 & 81 & 85 \\
Tot-COD $\left(\mathrm{mg} \mathrm{l}^{-1}\right)$ & & 58768 & 55614 & 88512 \\
Sol-COD $\left(\mathrm{mg} \mathrm{l}^{-1}\right)$ & & 4954 & 4318 & 4702 \\
OLR $\left(\mathrm{kg} \mathrm{VS} \mathrm{m}^{-3} \mathrm{~d}\right)$ & 2.0 & 2.0 & 3.5 \\
OLR $\left(\mathrm{kg} \mathrm{COD} \mathrm{m}^{-3} \mathrm{~d}\right)$ & & 3.9 & 3.7 & 5.9 \\
Type of substrate & & $\mathrm{SS}$ & $\mathrm{SS}(80 \%)-\mathrm{GS}(20 \%)$ & $\mathrm{SS}(40 \%)-\mathrm{GS}(60 \%)$ \\
Alkalinity $\left(\mathrm{mg} \mathrm{CaCO}_{3} \mathrm{I}^{-1}\right)$ & & 4950 & 5400 & 5760 \\
CST $(\mathrm{s})$ & 53 & 103 & 63 \\
Foaming Potential $(\mathrm{ml})$ & & 320 & 305 & 198 \\
Foaming stability $(\mathrm{s})$ & & 350 & 486 & 81 \\
\hline
\end{tabular}

\section{Batch tests}

Methane potential of SS and GS separately along with a mixture of SS and GS on a 1:1 ration (on VS basis) was determined in duplicate by anaerobic digestion batch tests. Batch tests were performed in $160 \mathrm{ml}$ serum bottles under mesophilic conditions $\left(35^{\circ} \mathrm{C}\right)$. Liquid volume was equal to $100 \mathrm{ml}$ and consisted of a mixture of mesophilic anaerobically digested sludge (inoculum) and substrate. The organic loading for each batch test was set to $2 \mathrm{~kg} \mathrm{VS} \mathrm{m}^{-3}$. Each serum bottle sealed with a Teflon-faced butyl rubber stopper and aluminum crimp cap, and purged with nitrogen gas. The batch tests were incubated with magnetic stirring at $35^{\circ} \mathrm{C}$. Periodically, samples were taken from the headspace of the serum bottles to measure methane production and twice (once at the beginning and once at the end) from the liquid phase to analyze total and volatile solids. Upon sampling the headspace was flushed with nitrogen gas. The experiment was terminated when methane production ceased.

\section{Analyses}

Data collection for the continuous digestion runs commenced after three times the operating hydraulic retention time and were analyzed for total and volatile solids (TS and VS), total and soluble chemical oxygen demand (COD), volatile fatty acids (VFA) and alkalinity according to Standard Methods (APHA-WEF-AWWA, 1992). The dewaterability of the digested sample was determined by capillary suction time (CST) as detailed in Standard Methods with Whatman No.17 chromatography 
grade paper. The foaming potential and the foaming stability were measured according the Alka Seltzer test developed by $\mathrm{Ho}$ et al. (1992) but due to the fact that Alka Seltzer tablets are commercially unavailable in Greece, Panadol Extra tablets that contain the same active substances (sodium bicarbonate and citric acid) were used instead.

Biogas was collected in inverted cylinders placed in a compartmentalized tank with acidified water and sludge gas production rates were measured by the water displacement method (Figure 2). Samples were abstracted from the headspace of each reactor (continuous and batch systems) with a gas-tight syringe $(1 \mathrm{ml})$ and were placed in $60-160 \mathrm{ml}$ serum bottles sealed with Teflon-faced butyl rubber stoppers. Methane was measured with a Perkin-Elmer Autosystem XL gas chromatograph equipped with a PLOT column GS-GasPro (30 m, $0.32 \mathrm{~mm}$ diameter, J\&W, Folsom, CA) and flame ionization detector (FID) by injecting $50 \mu \mathrm{l}$ of sample headspace with a gas-tight syringe $(100 \mu \mathrm{l})$. Analyses were conducted using an isothermal method $\left(50^{\circ} \mathrm{C}\right)$ while injector and detector were held at $220^{\circ} \mathrm{C}$ and $250^{\circ} \mathrm{C}$, respectively. Standards were prepared by adding a known amount to serum bottles of $160 \mathrm{ml}$ that had the same ratio headspace/liquid as the reactor (6:10). Detection limit for methane measurements was $2 \mu \mathrm{g} \mathrm{I}^{-1}$.

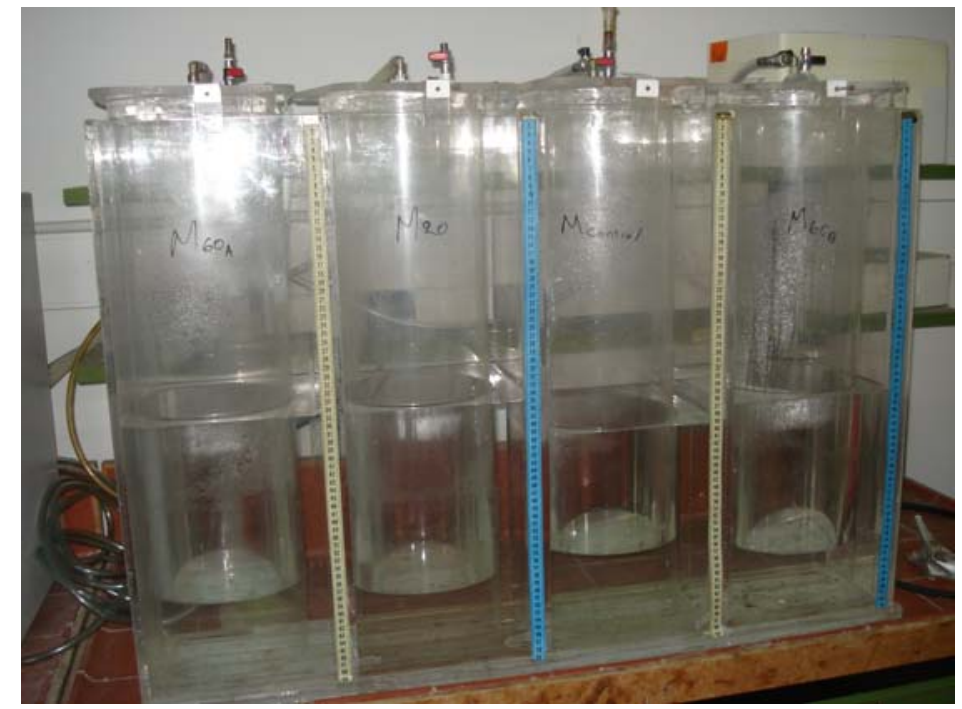

Figure 2. Biogas collection and measurement unit

\section{RESULTS AND DISCUSSION}

\section{Continuous anaerobic digestion systems}

As already mentioned three lab - scale anaerobic reactors were operated at mesophilic conditions for a period of 140 days. One system (System C) was fed on a mixture of thickened PS and WAS (SS) and its operation was compared to the operation of the two experimental units which were fed on two different mixtures of SS and GS as well as two different organic loadings (systems E1 and E2). Feed composition for the three digestion units is presented in Table 1. Due to the significant content of GS (60\% on VS basis) VS: TS ratio of feed for system E2 was $85 \%$ whereas the respective ratios of feed for systems $\mathrm{C}$ and $\mathrm{E} 1$ were $75 \%$ and $81 \%$. Furthermore almost $8 \%$ of the feed COD was in soluble form for systems $C$ and $E 1$ whereas the respective value of feed for system E2 was $5 \%$ of the total COD. Another interesting observation is that the addition of high lipids quantities in the feed of system E2 resulted in significant lower foaming potential and foaming stability values with respect to the ones of the other two experimental units (systems $C$ and E2).

Anaerobic reactors performance data are presented in Table 2. Based on experimental results it can be stated that all three experimental units exhibited stable operation with significant VS reduction rates (57\% for system $\mathrm{C}$, and $59 \%$ for systems E1 and E2) and total and soluble COD reduction rates $(62 \%$ and $65 \%$ respectively for system C, $60 \%$ and $70 \%$ respectively for system E1 and $54 \%$ and $68 \%$ respectively for system E2). Steady state $\mathrm{pH}$ values in all experimental units were in the order of 7.2-7.3. VFA concentration for systems $C$ and $E 1$ were to the order of $650 \mathrm{mg} \mathrm{I}^{-1}$ whereas higher concentrations (greater than $1000 \mathrm{mg} \mathrm{l}^{-1}$ ) were measured for system E2. Despite the significant VFA concentrations, biogas production of system E2 was satisfactory. This can be 
explained by the relatively moderate values of VFA: alkalinity ratio which were recorded throughout the experimental period (lower than 0.2) for system E2. Systems C and E1 show a significant decrease in both foaming potential and foaming stability values (to the order of $50 \%$ and $70 \%$ respectively), whereas, interestingly enough, this was not the case for system E2.

Figure 3 presents the evolution of biogas production of the three experimental units after steady state conditions were achieved. It should be noted that biogas production of the control unit was similar to biogas production of the anaerobic digesters of PWTP $\left(0.41 \mathrm{~m}^{3} \mathrm{~kg}^{-1} \mathrm{VS}\right.$ added $)$.

Biogas yield for the three experimental units were $0.64 \mathrm{~m}^{3} \mathrm{Kg}^{-1} \mathrm{VS}$ added for system E2, $0.51 \mathrm{~m}^{3} \mathrm{~kg}^{-1}$ VS added for system E1 and $0.43 \mathrm{~m}^{3} \mathrm{~kg}^{-1} \mathrm{VS}$ added for system C. Thus the results clearly indicate that the addition of GS can lead to a satisfactory increase in biogas production in anaerobic digesters treating sewage sludge. The co-digestion of SS and GS at ratios of $20 \%-60 \%$ resulted in increased biogas yield of 18-50 \% (lower values correspond to lower GS content).

Table 2. Experimental results from anaerobic digestion units operation

\begin{tabular}{lccc}
\hline Parameter & System C & System E1 & System E2 \\
\hline TS $(\%)$ & 2.3 & 2.1 & 3.0 \\
VS $(\%)$ & 1.3 & 1.2 & 2.2 \\
VS/TS $(\%)$ & 57.8 & 56.7 & 72.5 \\
Tot-COD $\left(\mathrm{mg} \mathrm{l}^{-1}\right)$ & 22314 & 21976 & 40512 \\
Sol-COD $\left(\mathrm{mg} \mathrm{l}^{-1}\right)$ & 1736 & 1296 & 1509 \\
VFA $\left(\mathrm{mg} \mathrm{l}^{-1}\right)$ & 651 & 664 & 1086 \\
$\mathrm{pH}$ & 7.3 & 7.2 & 7.2 \\
Alkalinity $\left(\mathrm{mgCaCO}_{3} \mathrm{I}^{-1}\right)$ & 6240 & 5400 & 5760 \\
VFA/Alkalinity & 0.10 & 0.12 & 0.19 \\
CST $(\mathrm{s})$ & 11 & 14 & 12 \\
Foaming Potential $(\mathrm{ml})$ & 162 & 218 & 95 \\
Foaming stability $(\mathrm{s})$ & 101 & 150 & 65 \\
VS reduction $(\%)$ & 57 & 59 & 59 \\
Tot-COD reduction $(\%)$ & 62 & 60 & 54 \\
Sol-COD reduction $(\%)$ & 65 & 70 & 68 \\
Biogas production $\left(\mathrm{m}^{3} \mathrm{~kg}^{-1}\right.$ VS added) & 0.43 & 0.51 & 0.64 \\
Biogas production $\left(\mathrm{m}^{3} \mathrm{~kg}^{-1}\right.$ COD added) & 0.23 & 0.27 & 0.39 \\
Biogas production $\left(\mathrm{m}^{3} \mathrm{~kg}^{-1}\right.$ VS destroyed) & 0.75 & 0.87 & 1.09 \\
Biogas production $\left(\mathrm{m}^{3} \mathrm{~kg}^{-1}\right.$ COD destroyed) & 0.37 & 0.45 & 0.72 \\
\hline
\end{tabular}

The increase of biogas production through co-digestion of sewage sludge with grease trap sludge is also reported by Luostarinen et al. (2009), Davidsson et al. (2008) and Kabouris et al. (2009). However according to Luostarinen et al. (2009) an upper threshold value of $50 \%$ for GS in feed VS for feasible co-digestion was anticipated. Based on the present study stable digestion operation with increased biogas production can be achieved even at a $60 \%$ ratio of GS originated VS in total feed VS. These differences should be attributed to the greater OLR used by Luostarinen et al., (2009) compared to the OLR of system E2 (4.01 kg VS m $\mathrm{d}^{-1}$ as opposed to $\left.3.5 \mathrm{~kg} \mathrm{VS} \mathrm{m}^{-3} \mathrm{~d}^{-1}\right)$ and the origin of GS used on the experiments of the two studies (grease trap sludge from a metal processing plant as opposed to grease sludge collected in the wastewater treatment plant). Based on the experimental results it was also observed that no additional sludge is produced at system E1 as compared to the sludge of system C.

It is interesting to note that during the early stages of operation of reactor E2 a lag phase was recorded before significant biogas production was initiated (Figure 4). As can be seen from Figure 4 the duration of this period was 15-20 days, during which low pH values to the order of 6.5 were followed by low biogas productivity $\left(0.2 \mathrm{~m}^{3} \mathrm{~kg}^{-1} \mathrm{VS}\right.$ added). This lag phase should be attributed to the acclimatization of acetogenic microorganisms which are capable to degrade the high LCFA content produced in the first step of anaerobic digestion of reactor E2. Similar observations regarding the occurrence of a lag phase in degradation of LCFAs during the start-up of anaerobic systems being fed by significant lipid containing substrates have been made by other researchers as well (Rinzema 1988, Hwu 1997, Cirne et al., 2007). Finally the operation of system E1 at a GS ratio of $90 \%$ in feed VS failed to reach stable operational conditions. More specifically after 16 days of 
operation, reactor's $\mathrm{pH}$ remained constantly low (below 6.0) with practically no biogas production and besides of everyday base addition to keep higher $\mathrm{pH}$ values no stable anaerobic process could be established. Similar results are reported by Davidsson et al. (2008). Whether this failure is exclusively due to the high OLR or to the high GS content, as well, needs further investigation.

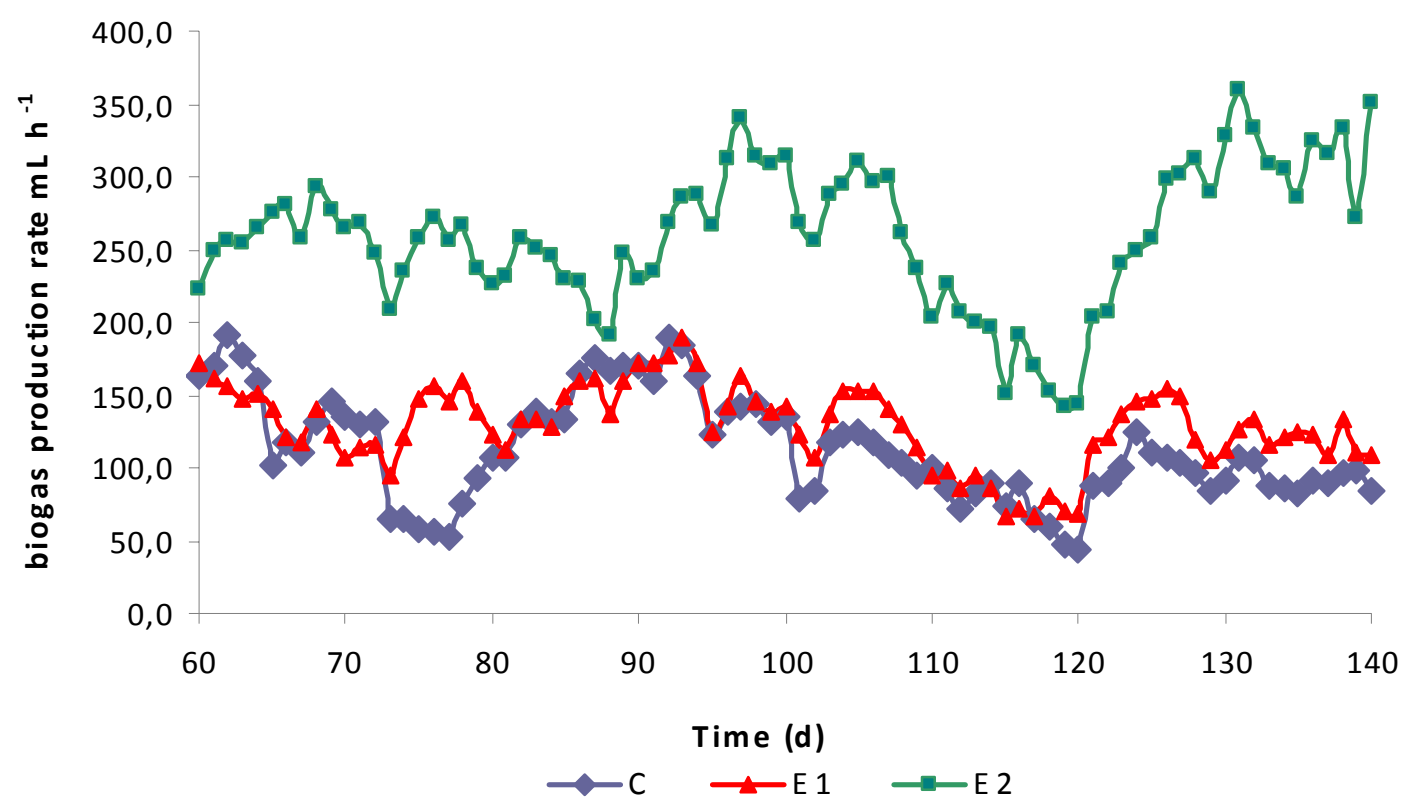

Figure 3. Evolution of biogas production for the three continuous anaerobic reactors for days $60-140$

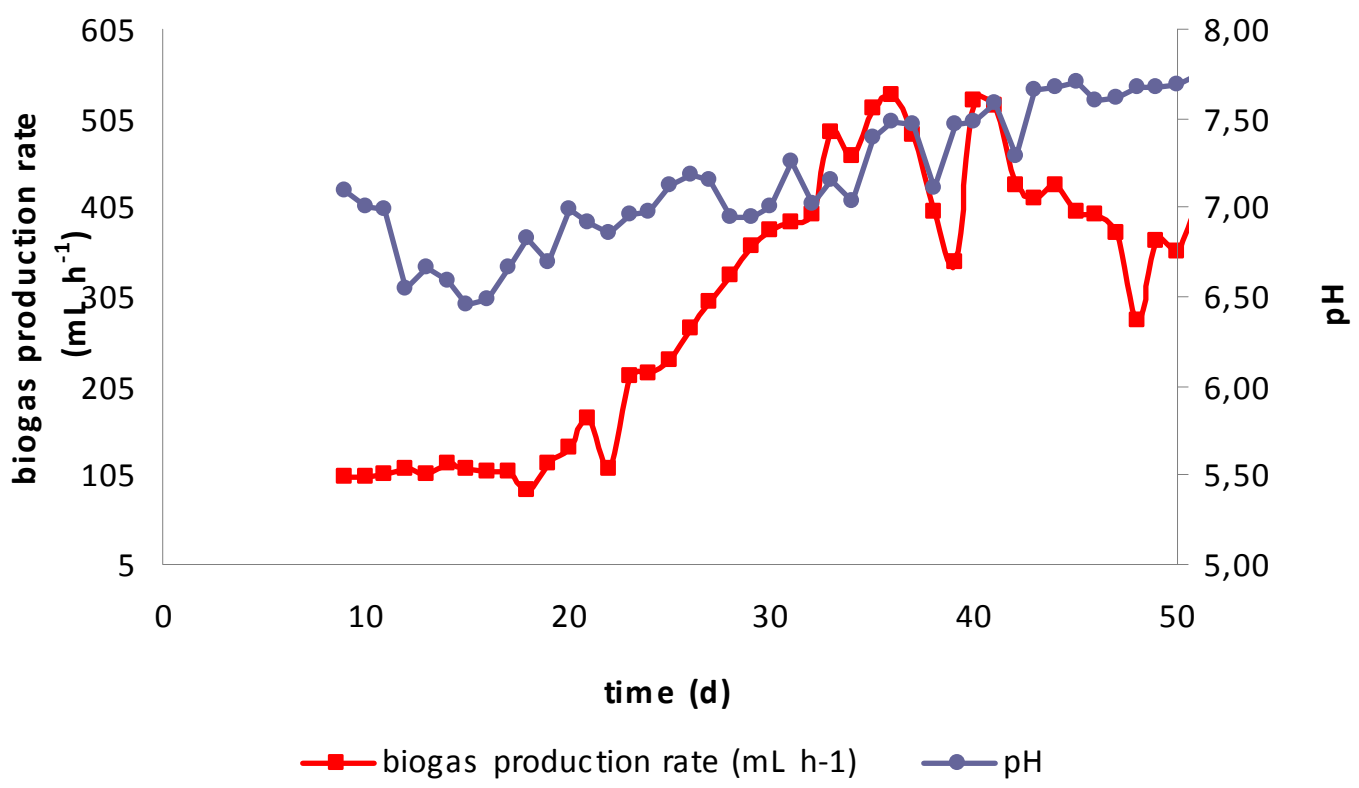

Figure 4. Evolution of biogas production and $\mathrm{pH}$ values during start-up period of system E2

\section{Batch tests}

The methane potential was determined through batch experiments which were performed for a period of 70 days. Results are presented in Figure 5. The methane potential of inoculum has been subtracted from the experimental results. Average methane potential of SS was comparatively low (155 NL $\mathrm{NH}_{\mathrm{Cg}} \mathrm{kg}^{-1} \mathrm{VS}$ added) whereas methane potential of GS and the mixture of GS and SS (at 1:1 ratio on VS basis) were equal to $572 \mathrm{NL}_{\mathrm{CH} 4} \mathrm{~kg}^{-1} \mathrm{VS}$ added and $300 \mathrm{NL}_{\mathrm{CH} 4} \mathrm{~kg}^{-1} \mathrm{VS}$ added. Since all batch experiments were performed under the same OLR $\left(2 \mathrm{~kg} \mathrm{VS} \mathrm{m}^{-3}\right)$ the differences on methane yields should be attributed to the elevated biodegradable portion of VS in GS as compared to SS. A 
lag phase in methane production was observed at batch experiments with GS and SS+GS mixture as substrate. According to the results it can be stated that the more GS content in the feed the longer the lag phase. A possible explanation for the duration of lag phase is the use of non acclimatized inoculums in the batch experiments. Finally it is interesting to note that the methane potential measured with GS as a sole substrate is lower than the theoretical one $\left(1 \mathrm{NL}_{\mathrm{CH} 4} \mathrm{~kg}^{-1} \mathrm{VS}\right.$ added) which is an indication that GS used in the present study exhibits different characteristics than pure lipids.

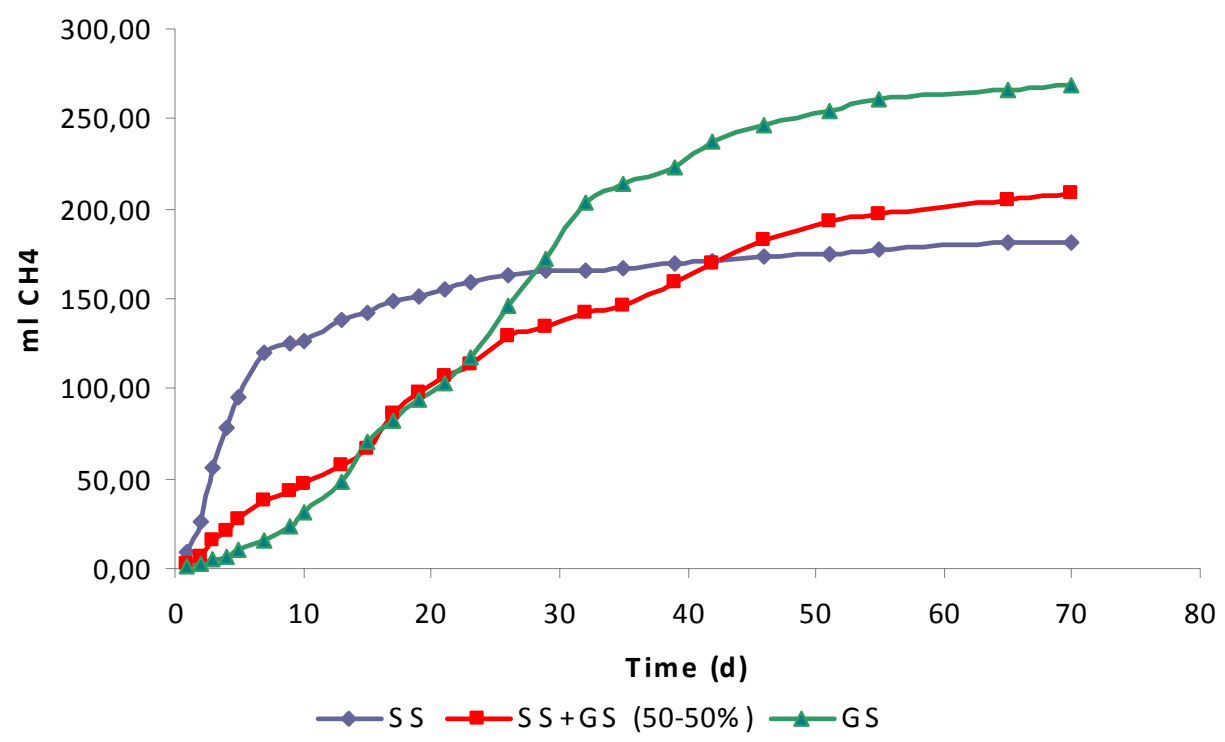

Figure 5: Methane production for SS, GS and mixture of SS and GS.

\section{CONCLUSIONS}

The objective of this study was to assess the feasibility of co-digesting lipids (fats, oils, greases) originated from domestic wastewater along with sewage sludge and to evaluate the effect of operational parameters such as the organic loading and lipids content on the performance of anaerobic digestion. According to the results it can be stated that the addition of GS up to a VS feed ratio of $60 \%$ and an organic loading rate of $3.5 \mathrm{~kg} \mathrm{VS} \mathrm{m}^{-3} \mathrm{~d}^{-1}$ can lead to an increased biogas production (to the order of $50 \%$ ) without creating any detrimental effect on anaerobic digestion. Although such VS feed ratios of lipids through the addition of grease sludge collected inside the wastewater treatment plant to sewage sludge are rather high, significant benefits from co-digestion of this material along with sewage sludge are anticipated due to the increased biogas production (depending on the feed VS ratio of GS) and the avoidance of GS management costs (landfilling).

\section{REFERENCES}

Alves M.M., Pereira M.A., Sousa D.Z., Cavaleiro A.J., Picavet M., Smidt H. and Stams A.J.M., (2009). Waste lipids to enery: how to optimize methane production from log chain fatty acids (LCFA)minireview, Microbial Biotechnology, 2(5) 538-550.

Andreasen K. and Nielsen P.H., (2000). Growth of Microthrix Parvicella in nutrient removal activated sludge plants: studies of in situ physiology, Wat. Res., 34 1559-1569.

Angelidaki I. and Ahring B.K., (1992). Effects of free long chain fatty acids on thermophilic anaerobic digestion, Applied Microbiology and Biotechnology, 37, 808-812.

Angelidaki I. and Ahring B.K., (1997). Codigestion of olive oil mill wastewater with manure, household waste or sewage sludge, Biodegradation, 8, 221-226.

APHA - WEF - AWWA (1992) Standard Methods for Water and Wastewater Laboratory Analysis, $18^{\text {th }}$ Edition, Washington D.C., USA.

Chipasa K.B. and Medrzycka K., (2006). Behavior of lipids in biological wastewater treatment processes' Journal Ind, Microbiol. Biotechnol., 33, 635-645.

Cirne D.G., Paloumet X., Björnsson L., Alves M.M. and Mattiasson B., (2007). Anaerobic digestion of lipid-rich waste - Effects of lipid concentration, Renewable energy, 32, 965-975. 
Davidsson A., Lövstedt C., Jansen J., Gruvberger C. and Aspegren H., (2008). Co-digestion of grease trap sludge and sewage sludge, Waste Management, 28, 986-992.

Hanaki K., Matsuo T. and Nagase M. (1981). Mechanism of inhibition caused by long chain fatty acids in anaerobic digestion process, Biotechnology and Bioengineering, 23, 1591-1610.

Ho C.F. and Jenkins D., (1991), The Effect of Surfactants on Nocardia Foaming in Activated Sludge, Wat. Sci. Tech., 23, 879-888.

Hwu C. and G. Lettinga (1997). Acute toxicity of oleate to acetate-utilizing methanogens in mesophilic and thermophilic anaerobic sludges, Enzyme and Microbial Technology, 21, 297-301.

Hwu C.S., van Lier J.B. and Lettinga G., (1998). Physicochemical and biological performance of expanded granular sludge bed reactors treating long chain fatty acids, Process Biochemistry, 33, 7581.

Kabouris J.C., Tezel U., Pavlostathis S.G., Engelmann M., Dulanay J., Gillette R. and Tood A.C., (2009). Methane recovery from the anaerobic co-digestion of municipal sludge and FOG, Bioresource Technology, 100, 3701-3705.

Kim H.W., Han S.K. and Shin H.S., (2004). Anaerobic co-digestion of sewage sludge and food waste using temperature-phased anaerobic digestion process, Wat. Sci. Tech., 50, 9, 107-114.

Luostarinen S., Luste S. and Sillanpää M. (2009). Increased biogas production at wastewater treatment plants through co-digestion of sewage sludge with grease trap sludge from a meat processing plant, Bioresource Technology, 100, 79-85.

Mamais D., Andreadakis A., Noutsopoulos C. and Kalergis K. (1998). Causes and control strategies for Microthrix parvicella bulking and foaming in nutrient removal activated sludge systems, Wat. Sci. Tech. 37 9-17.

Noutsopoulos C., Andreadakis A., Mamais D. and Gavalakis E., (2007). Identification of type and causes of filamentous bulking under Mediterranean conditions, Environmental Technology, 28, 115-122.

Noutsopoulos C., Mamais D. and Andreadakis A. (2010). Long chain fatty acids removal in selector tanks: Evidence for insufficient Microthrix parvicella control, Desalination and Water, 23, 1-3, 20-25.

Quemeneur M. and Marty Y. (1994). Fatty acids and sterols in domestic wastewater, Wat. Res., 28, 5, 1217-1226.

Raunkjaer K., Hvitved-Jacobsen T. and Nielsen P.H., (1994). Measurement of pools of protein, carbohydrate and lipid in domestic wastewater, Water Research, 28, 251-262.

Rinzema A., Boone M., van Knippenberg K. and Letinga G., (1994). Bactericidal effect of long chain fatty acids in anaerobic digestion, Water Environmental Research, 66, 40-49. 